\title{
DYNAMIC EVOLUTION CHARACTERISTICS AND MECHANISM OF SURROUNDING ROCK FRACTURES DURING THE REPEATED MINING OF CLOSED DISTANCE DEEP COAL SEAM
}

\author{
Jiazhuo $\mathrm{LI}^{1,2 *}$, Zhenhua JIAO ${ }^{2}$, Ming ZHANG ${ }^{2}$ and Yang $\mathrm{LI}^{3}$
}

${ }^{1}$ State Key Laboratory of Mining Response and Disaster Prevention and Control in Deep Coal Mines, Anhui University of Science and Technology, Huainan 232001, China

${ }^{2}$ School of Resource and Safety Engineering, Anhui University of Science and Technology, Huainan 232001, China

${ }^{3}$ Science and Technology Development Department, Shenhua Group Corporation Limited

*Corresponding author: jiazhuo312@126.com

(Received May 2018; accepted July 2018)

Key words: coal seam, repeated mining, surrounding rock in the stope, fracture evolution, mechanism

\begin{abstract}
The disturbance mechanics behavior and mechanics mechanism of repeated mining of coal seam group are the important theoretical basis for safe mining of deep coal seam group. For the characteristics of interaction among coal seams under the condition of combined mining of coal seam group, in this paper, the spatio-temporal evolution characteristics of 3D mining stress field and the law of strata activity in repeated mining of deep coal seam group were studied by using similar material simulation and numerical simulation methods. The results showed that during the first mining, overburden mining broke the initial stress balance; part of the surrounding rock stress was released and free space was formed; rock mass moved to the direction of goaf, which released the pressure and protected the rock mass; a caving arch was formed in the overburden strata of coal seam whose arch trace was composed of the boundary line of separated strata and the fracture line of rock beam. As the working face continued to advance, the exposed strata in the arch gradually transferred and expanded to the upper strata, and the separated strata also gradually propagated upward, thus forming the periodic failure process of the caving arch. During repeated mining, the upper coal seam underwent the support and compaction process of caving, natural filling, the integrity of the main roof of the underlying coal seam was destroyed, all the interlayer strata collapsed or broke, and were connected with the goaf of the upper coal seam working face, resulting in the fractured rock mass of the goaf directly transferring load downward, and then the periodic weighting of mining was relaxed. The results have certain reference value for the combined mining of coal seams under similar conditions.
\end{abstract}

Palabras clave: grupo de minería de carbón, minería repetida, roca circundante en el realce, evolución de fracturas, mecanismo mecánico 


\section{RESUMEN}

Las alteraciones del comportamiento mecánico y de los mecanismos de la explotación de carbón repetida son bases teóricas importantes para la minería de carbón segura a profundidad. Para conocer las características de las interacciones en las vetas de carbón bajo condiciones de explotación combinada, en este trabajo se estudió la evolución espacio temporal en 3D del campo de estrés y de la ley de estratos durante la explotación repetida, utilizando métodos de simulación material similar y métodos numéricos de simulación. Los resultados mostraron que durante la primera explotación la sobrecarga rompió el balance de estrés inicial; parte del estrés de las rocas circundantes se liberó y se formó un espacio libre; la masa de rocas se dirigió hacia el depósito, lo que liberó la presión y protegió a la masa de rocas; se formó una cavidad en arco en el estrato con sobrecarga de la veta, delimitada por la línea de frontera de los estratos separados y la línea de fractura del soporte de la roca. Al continuar el avance de la facie de trabajo, los estratos expuestos en la cavidad en arco se transfirieron y expandieron gradualmente hacia los estratos superiores y los estratos separados también se propagaron hacia arriba, formando entonces el proceso de falla periódica de la cavidad en arco. Durante la explotación repetida la veta superior experimentó el proceso de soporte, compactación y relleno natural y la integridad del techo de roca principal de la veta subyacente se destruyó, todos los estratos de las capas intermedias se colapsaron o rompieron y se conectaron con el depósito de la facie de trabajo de la veta superior, lo que resultó en la transferencia hacia abajo de la carga de la masa de roca fracturada del depósito y, entonces, se relajó la peso periódico de la explotación. Los resultados tienen cierto valor de referencia para la minería combinada de vetas de carbón bajo condiciones similares.

\section{INTRODUCTION}

Coal plays a dominant role in China's primary energy consumption structure. For example, in 2016, China's coal consumption accounted for $64 \%$ of China's total energy consumption (Fu and Liu 2017, Yang et al. 2017, Grzeczka and Szymak 2016, Razali et al. 2017, Azizan et al. 2017). The rapid development of economy buoys the coal production, as underground coal mining depth gradually increases, even to $1000 \mathrm{~m}$ in some areas, and still rapidly extends to the deep at an average speed of $10 \mathrm{~m} / \mathrm{a}-25 \mathrm{~m} / \mathrm{a}$ (Xie 2017, Fan and Qin 2017). Especially in the economically developed areas with a long history of coal exploitation in central and eastern China, the shallow coal resources have been nearly exhausted, and many coal mines have entered deep mining (800 m - $1500 \mathrm{~m}$ buried depth). In Huainan mining area, there are as many as 12 minable coal seams, and the mining depth of most coal mines is $800 \mathrm{~m}-1000 \mathrm{~m}$ (Kim et al. 2018, Danielson et al. 2016, Ahamed et al. 2017, Daya and Pant 2017).

Experts at home and abroad have carried out indepth theoretical researches on single coal seam mining, and have achieved rich and systematic theoretical results, which lays a theoretical foundation for coal mining. For example, Z. D. H. Steve et al. studied the permeability change of coal body in front of longwall stoping face due to supporting pressure. (Steve et al.
1999, Ong et al. 2017) studied the interaction between permeability and effective stress of gas-bearing coal seam and concluded that there is an exponential relationship between permeability change and in-situ stress change in the gas-bearing coal seam (Eneyer and Henning 1997, Mohammed 2018). Based on the geological conditions of coal seam occurrence and the ground object field environment, S. Harpalaini and M. J. Mopherson investigated and studied the mechanical properties of gas-bearing coal samples and the mechanical effects of solid-gas coupling between gas seepage and coal rock mass under experimental conditions (Harpalani and Mopherson 1984, Nawaz et al. 2018).

In the research field of dynamic development of mining-induced fractures in overlying strata, Qian Minggao et al. proposed the key strata theory, which provides a theoretical basis for the further study of the law of strata movement and deformation and the dynamic process of evolution of mining-induced fractures (Minggao et al. 2018, Asghar et al. 2018). A group researcher analyzed the influence of the activity of key strata in overlying strata on the development of fractured zones after coal seam mining, and first put forward the distribution characteristics of elliptical parabola in overlying strata due to the connectivity between separated strata and vertical broken fractures (Shugang et al. 2016, Basheer et al. 2017). Gao Kui et al. studied the spatiotemporal 
evolution mechanism of overlying strata fractures in the coal seam mining process, and the results show that: In the coal seam mining process, inconsistent deformation between overlying strata was produced, which will have a great influence on the distribution and formation of various fractures in the course of strata movement (Kui et al. 2015, Zahan et al. 2017).

Through a large number of laboratory tests, Y.Bernabe et al. studied the relationship between gas pore pressure, surrounding rock and permeability, as well as the mechanical properties of gas-bearing coal (Bernabe et al. 1986). Some scientists developed RFPA2D, a rock failure process analysis software, by which they studied the whole process of rock failure from meso-damage to macroscopic failure and the seepage flow in the rock failure process (Duanyang et al. 2017). Other researchers obtained the dynamic evolution law of surrounding rock structure along the goaf side of stopping face after mining above the closed distance coal seam and multi-face on the wing side, which can guide the layout and maintenance of roadway along the goaf side (Xiaoming et al. 2014). $\mathrm{Tu}$ Shihao et al. studied the law of rock pressure behavior caused by closed distance coal seam mining under shallow buried room and pillar goaf and put forward the control and prevention measures such as roof caving and pressure relief by residual coal pillar blasting, filling of coal house by surface drilling and sand injection, and reasonable control of mining height (Shihao et al. 2011). Other researchers studied the progressive rupture process of overlying strata in longwall stope under closed distance room and pillar goaf and the development and evolution law of mining-induced fractures and analyzed the change of strata migration from the angle of energy release (Zhen et al. 2012).

However, different from the single coal seam mining, the deep coal seam group mining faces a more complex surrounding rock force system due to the combined action of deep high stress and repeated mining, thus the mining destroys the integrity of postmining coal seam roof and floor. Moreover, a more complex stress superposition evolution is formed due to the influence of pressure relief in adjacent pre-mining coal seam and coal pillar stress concentration transfer in residual section. With the increase of mining depth, the mine pressure behavior of mining roadway becomes serious, and the mine pressure behavior of panel also becomes increasingly serious $(\mathrm{Li}$ 2017). Moreover, the repeated destruction of mining roadway and panel is aggravated by repeated mining, making it more difficult to control their stability and safety. The imperfect basic theory system of coal seam group mining causes the preservation of a large number of section protective coal pillars in the mining process, so the high quality resources cannot be recovered, resulting in great waste. Moreover, the effective prevention and control technology of deep coal seam group mining disaster is difficult to break through, so accidents occur frequently, causing great harm. Therefore, it is of great practical significance for the safe mining of deep high gas coal seam group by revealing the dynamic characteristics of 3D mining stress field and the temporal and spatial evolution law of its fractures and displacements in repeated mining of deep coal seam group.

\section{MATERIALS AND METHODS}

\section{Geological conditions of coal seam group working face}

Xinzhuangzi Coal Mine, with a coal output of 3 million tons, is one of the old mining areas of Huainan Mining Group adopting the coal seam group mining mode. The average distance between No.7 coal seam and No. 8 coal seam was $12 \mathrm{~m}$. For the panel 66207, its elevation was $-721 \mathrm{~m}--793 \mathrm{~m}$, average thickness of coal seam was $3.0 \mathrm{~m}$, slant length was $132 \mathrm{~m}$, strike length was $535 \mathrm{~m}$, and dip angle of coal seam was $30^{\circ}$. The geological section of the panel 66207 is shown in Fig.1. For the panel 66208, its elevation was $-696 \mathrm{~m}--801 \mathrm{~m}$, average thickness of coal seam was $1.9 \mathrm{~m}$, slant length was $170 \mathrm{~m}$, strike length was $742 \mathrm{~m}$, and dip angle of coal seam was $30^{\circ}$. The geological section of the panel 66207 is shown in Fig.2. The comprehensive histogram of the panels is shown in Fig. 2. From Figs. 1, 2, it can be found that the mining time of the panel 66207 corresponding to the overlying Panel 66208 was relatively short, the complex stress field and displacement field caused by mining were superimposed on each other, and the temporal and spatial relationship of mine pressure behavior was complex.

The mining technical conditions of the panel 66207 were similar to adjacent panel 66107 that had finished mining, which can provide certain reference for the safety and high efficiency production design of the panel 66207. For the panel 66107, its elevation was $-595 \mathrm{~m}--693 \mathrm{~m}$, average thickness of coal seam was $3.8 \mathrm{~m}$, slant length was $215 \mathrm{~m}$, strike length was $350 \mathrm{~m}$, and dip angle of coal seam was $23^{\circ}$. Affected by the mining of overlying panel 66108 , the panel 66107 experienced violent spalling and roof falling in the mining process, with an average daily advance of only $1.36 \mathrm{~m}$, and monthly advance of $40.71 \mathrm{~m}$, 


$$
C_{t}=\sqrt{C_{l}}=\sqrt{1 / 100}=1 / 10
$$



Fig. 1. Geological section of the panel 66207

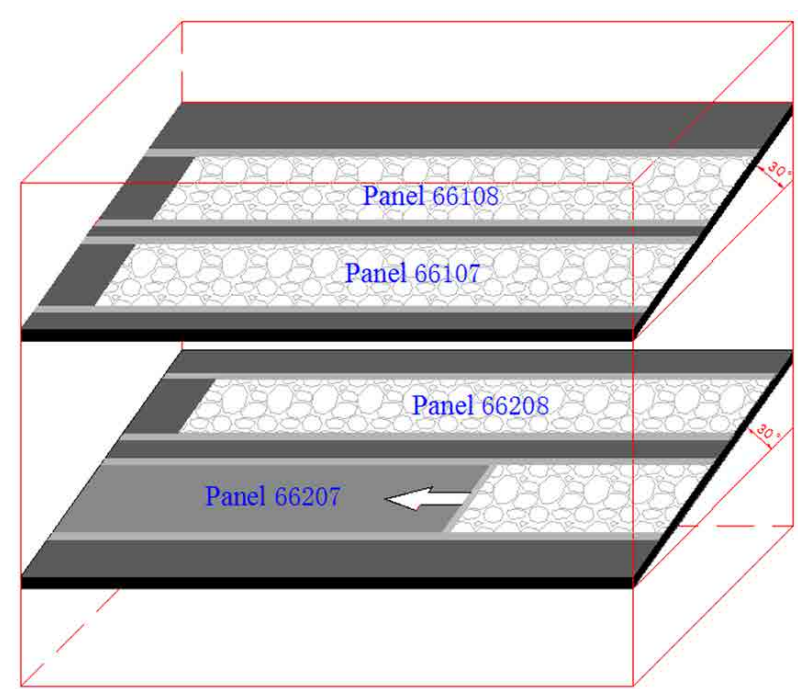

Fig. 2. Comprehensive histogram of the panels

which seriously affected its safe and efficient production. However, the roof strata of the panel 66207 were destroyed in the mining of the panel 62208 and a natural false roof was formed. The coal seam in the panel 66207 was mainly soft coal, and the compressive strength, shear strength and cohesion force were very small, which further increased the possibility of coal wall spalling in the panel 66207.

\section{Calculation model and calculation parameters}

Based on the geological conditions of the panel 66207 of Xinzhuangzi Coal Mine of Huainan Mining Group, FLAC3D, a three-dimensional computational model, was established for numerical simulation. For the model, its strike length was $442 \mathrm{~m}$, slant width was $500 \mathrm{~m}$, and height was $479.2 \mathrm{~m}$. The model consisted of No.7 coal seam and No.8 coal seam as well as their roof and floor strata. The coal seam by model simulation was consistent with the field coal seam, with a dip angle of $30^{\circ}$. Horizontal movement was restricted on the side of the model, vertical movement was restricted on the bottom of the model, and vertical load was applied on the upper part of the model to simulate the weight of overlying strata. The failure of rock mass was judged by Mohr-Coulomb yield criterion, and the properties of residual strength gradually decreasing with the development of deformation were reflected by strain softening model. The mechanical parameters of the rock mass are shown in Table $\mathbf{I}$. 
TABLE I. MECHANICAL PARAMETERS OF THE ROCK MASS.

\begin{tabular}{|c|c|c|c|c|c|c|c|c|}
\hline Rock name & $\begin{array}{c}\text { Bulk } \\
\text { density d } \\
\left(\mathrm{kN} / \mathrm{m}^{3}\right)\end{array}$ & $\begin{array}{l}\text { Elasticity } \\
\text { modulus E } \\
(\mathrm{MPa})\end{array}$ & $\begin{array}{c}\text { Poisson } \\
\text { ratio } \\
\text { m }\end{array}$ & $\begin{array}{l}\text { Cohesion } \\
\mathrm{c}(\mathrm{MPa})\end{array}$ & $\begin{array}{c}\text { Friction } \\
\text { angle } \\
\varphi\left(^{\circ}\right)\end{array}$ & $\begin{array}{c}\text { Bulk } \\
\text { modulus } \\
(\mathrm{MPa})\end{array}$ & $\begin{array}{l}\text { Shear } \\
\text { modulus } \\
(\mathrm{MPa})\end{array}$ & $\begin{array}{c}\text { Tensile } \\
\text { strength } \\
\sigma_{\mathrm{T}}(\mathrm{MPa})\end{array}$ \\
\hline $\begin{array}{l}\text { Fine sand and sandy } \\
\text { mudstone }\end{array}$ & 15.66 & $0.29 \times 10^{4}$ & 0.38 & 1.02 & 24 & 4028 & 1051 & 0.52 \\
\hline Medium sandstone & 25.10 & $0.54 \times 10^{4}$ & 0.15 & 2.19 & 30 & 2571 & 2348 & 0.72 \\
\hline $\begin{array}{l}\text { Medium grained } \\
\text { sandstone }\end{array}$ & 25.49 & $1.44 \times 10^{4}$ & 0.24 & 1.78 & 34 & 9231 & 5806 & 0.88 \\
\hline No.9 coal & 23.80 & $0.84 \times 10^{4}$ & 0.26 & 1.2 & 29 & 5833 & 3333 & 0.56 \\
\hline Siltstone & 27.00 & $2.4 \times 10^{4}$ & 0.20 & 2.78 & 40 & 13333 & 10000 & 1.35 \\
\hline Sandy mudstone & 22.48 & $0.79 \times 10^{4}$ & 0.26 & 1.22 & 28 & 5486 & 3135 & 0.5 \\
\hline No.8 coal & 27.09 & $2.54 \times 10^{4}$ & 0.22 & 2.95 & 40 & 15119 & 10410 & 1.55 \\
\hline Fine sandstone & 25.10 & $0.54 \times 10^{4}$ & 0.15 & 2.19 & 30 & 2571 & 2348 & 0.72 \\
\hline Sandy mudstone & 13.71 & $0.52 \times 10^{4}$ & 0.31 & 1.24 & 32 & 4561 & 1985 & 0.16 \\
\hline No.7 coal & 25.10 & $0.54 \times 10^{4}$ & 0.15 & 2.19 & 30 & 2571 & 2348 & 0.72 \\
\hline Mudstone & 27.09 & $2.54 \times 10^{4}$ & 0.22 & 2.95 & 40 & 15119 & 10410 & 1.55 \\
\hline No.6coal & 13.77 & $0.51 \times 10^{4}$ & 0.32 & 1.25 & 32 & 4722 & 1932 & 0.13 \\
\hline Mudstone & 26.65 & $2.32 \times 10^{4}$ & 0.17 & 2.61 & 41 & 11717 & 9915 & 1.21 \\
\hline Sandstone & 24.87 & $1.35 \times 10^{4}$ & 0.123 & 2.06 & 40 & 5968 & 6011 & 1.13 \\
\hline Mudstone & 24.61 & $0.875 \times 10^{4}$ & 0.26 & 1.2 & 30 & 6076 & 3472 & 0.605 \\
\hline $\begin{array}{l}\text { Medium and fine } \\
\text { sandstone }\end{array}$ & 26.65 & $2.32 \times 10^{4}$ & 0.17 & 2.61 & 41 & 11717 & 9915 & 1.21 \\
\hline
\end{tabular}

According to the results of field sampling and rock mechanical test, the rock mass was destroyed when the load reached the strength limit, and the residual strength decreased gradually with the development of deformation during the plastic flow after the peak. The failure of rock mass was judged by Mohr-Coulomb yield criterion, and the properties of residual strength gradually decreasing with the development of deformation were reflected by strain softening model (Xie 2018).

\section{Similar material simulation}

The similar material simulation test was carried out on a two-dimensional simulation test bench of China University of Mining and Technology (Beijing) (Fig. 3), whose size was 4,200 $\mathrm{mm}(L) \times$ $2000 \mathrm{~mm}(H) \times 250 \mathrm{~mm}(W)$. In the laying process, the geological conditions of the panel 66207 of Xinzhuangzi Coal Mine of Huainan Mining Group were strictly observed. The maximum thickness of each layer was $3 \mathrm{~cm}$, and mica powder was sprinkled between the layers to make the bedding parting clear, so as to ensure uniformity and stability as far as possible. The on-site production process of the model is shown in Fig. 4.

Because of the limitation of actual size of the similar simulation test bench, it was impossible to simulate the height of the strata to the surface all the time, so the weight of the overlying strata which

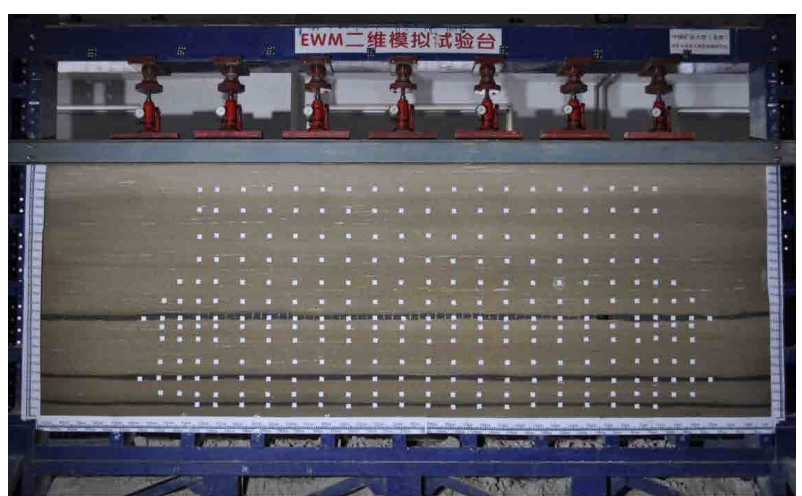

Fig. 3. The model

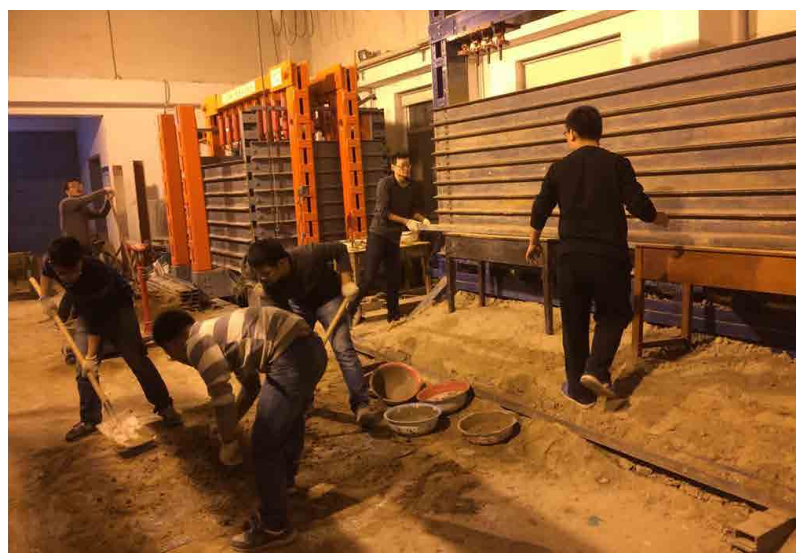

Fig. 4. The on-site production process of the model 
cannot be simulated above the model was replaced by using loading method. According to the purpose of the test and the condition of the equipment, the geometric similarity constant took $C_{l}=1 / 100$, and the overlying strata were replaced by artificial pressure. The bulk density similarity constant took $C_{\gamma}=$ 1/1.67, the stress similarity constant took $C_{\sigma}=C_{\gamma} \times$ $C_{l}=1 / 1.67 \times 1 / 100=1 / 167$, and the time similarity constant took $C_{t}=\sqrt{C_{l}}=\sqrt{1 / 100}=1 / 10$. If the panel 66207 was excavated $8 \mathrm{~m}$ per day, it was excavated $8 \mathrm{~cm}$ every 2 hours in the test.

The amount of material used in each layer was calculated by the following formula:

$G=l \times b \times h \times \gamma_{p}$

Where $G$ was the total weight of the simulated stratified material, $b$ was the width of the model, $l$ was the length of the model, $h$ was the thickness of the simulated stratified material, and $\gamma_{p}$ was the bulk density of the simulated rock layer.

The average mining depth of the panel 66207 was $650 \mathrm{~m}$. Considering that the simulated geometric similarity ratio of the model was $C_{l}=1 / 100$, and the laying height of the model was $1,700 \mathrm{~mm}$, in which, the height of roof strata was $940 \mathrm{~mm}$, the remaining height was supplemented through the leverage loading system above the model. The gravity compensation load to be applied in the model was:

$\mathrm{q}_{\mathrm{m}}=\mathrm{c}_{\gamma} \times \mathrm{c}_{1} \times \gamma_{\mathrm{p}} \times\left(H-H_{\mathrm{m}}\right)=8.32 \mathrm{t} / \mathrm{m}^{2}$

Where $\gamma_{p}$ was the average bulk density of overlying strata, which took the mean of $2,500 \mathrm{~kg} / \mathrm{m}^{3} ; H$ was the thickness of strata from the surface to the coal seam roof, that is, the depth of the coal seam, which took $650 \mathrm{~m} ; H_{m}$ was the thickness of strata above the coal seam roof, which took $94 \mathrm{~m}$.

Considering the cross-section area of the simulation test bench, the load to be applied in the lever loading system above the model was: $G=8.32 \mathrm{t} / \mathrm{m}^{2}$ $\times 4.2 \mathrm{~m} \times 0.25 \mathrm{~m}=8.74 \mathrm{t}$.

After the laying of the model was completed, the displacement measuring points were arranged at an interval of $15 \mathrm{~cm}$, and the measuring points in the key monitoring areas, such as opening, cutting, stoppage and so on, were encrypted. A total of 270 displacement measuring points were arranged. In the model, the sensor readings of strata stress were recorded by laying strain gauges in the overlying strata of coal seam. Finally, the stress and deformation of the overlying strata of coal seam along with the advance of panel were calculated. In the simulated mining process of panel, because the geometric similarity ratio between the model and the prototype was $1: 100,1 \mathrm{~cm}$ in the model corresponded to $1 \mathrm{~m}$ in the prototype. For a more intuitive representation of the process and results of the similar material simulation test, the test data in the model were replaced by the data in the prototype in this paper.

\section{RESULTS AND DISCUSSION}

\section{Temporal and spatial characteristics of surroun- ding rock fractures during the mining of deep coal seam group}

Fig. 5 shows the law of macroscopic caving and fracture development of surrounding rock in the stope along the coal seam strike during the initial mining of the fully mechanized panel 66208 (Li 2017). It can be seen from Fig. 5 that the law of macroscopical caving and fracture development had the following characteristics:

a. When the panel advance distance was less than $25 \mathrm{~m}$, there was no obvious response in the model. When the panel advance distance was 25 $\mathrm{m}$, the immediate roof experienced initial caving, whose height was up to $3.5 \mathrm{~m}$ and step distance was $25 \mathrm{~m}$. When the panel advance distance was $48 \mathrm{~m}$, the basic roof strata experienced initial fracture and suspended roof. At this time, separation layer fracture appeared above the roof of the stope, whose height was $35 \mathrm{~m}$. As the panel continued to advance, the immediate roof rock mass above the coal seam caved along with mining, and the basic roof strata experienced periodic fracture, and the periodic pressure step distance was $25 \mathrm{~m}-35 \mathrm{~m}$, and the pressure periodicity was obvious.

b. During the mining of the panel 66208 , obvious and stable caving zone, fracture zone and bending subsidence zone were formed in the overlying strata of the goaf from bottom to top.

c. During the mining of the panel 66208, a caving arch was formed in the overlying strata between two coal seams, and its arch trace line was composed of the boundary line of separated strata and the fracture line of rock beam. As the panel continued to advance, the strata exposed in the caving arch were gradually transferred and extended to the upper strata; the separated strata also propagated upward gradually, and then formed the periodic failure process of the caving arch. 


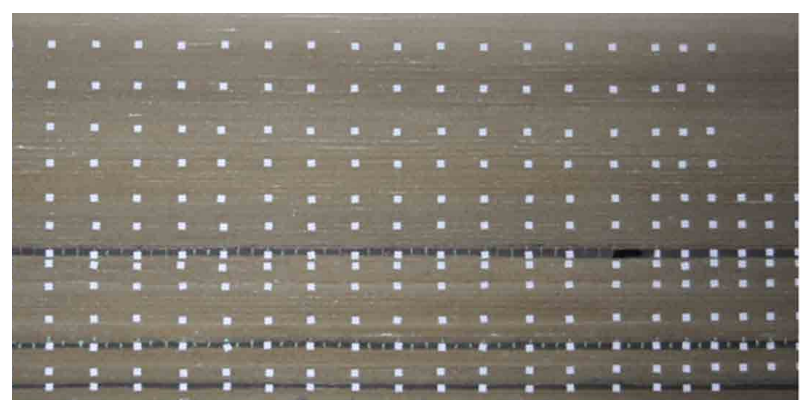

(a) Panel advance distance $25 \mathrm{~m}$

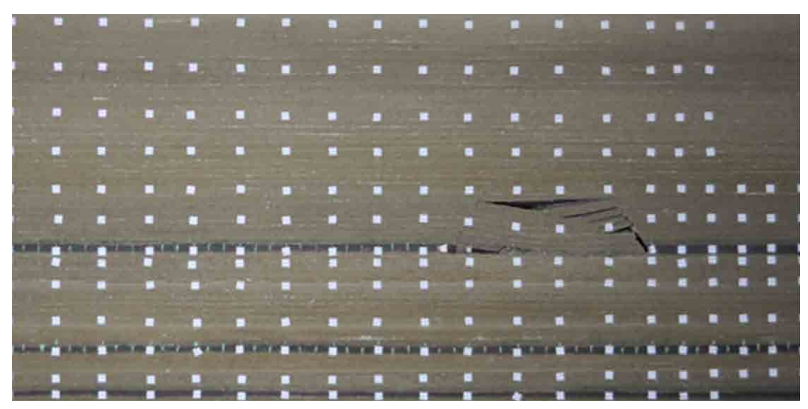

(c) Panel advance distance $75 \mathrm{~m}$

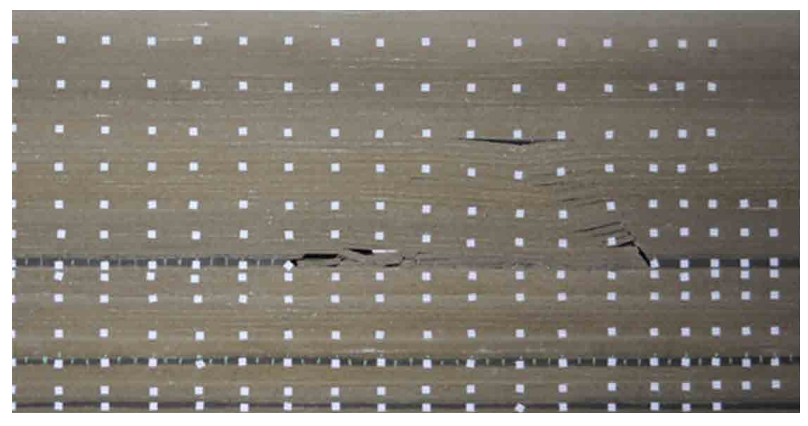

(e) Panel advance distance $125 \mathrm{~m}$

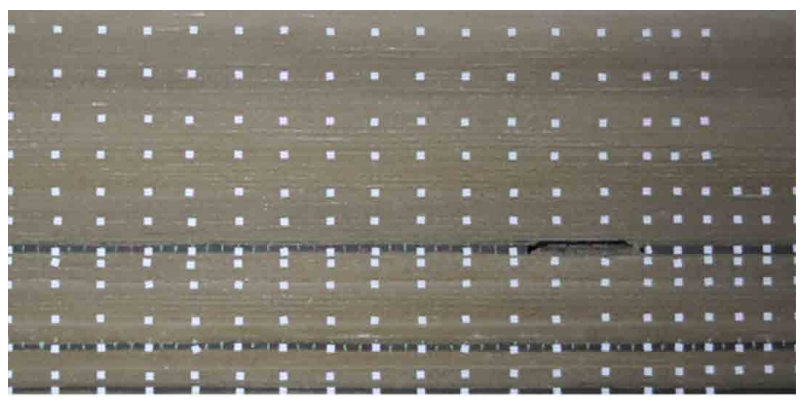

(b) Panel advance distance $50 \mathrm{~m}$

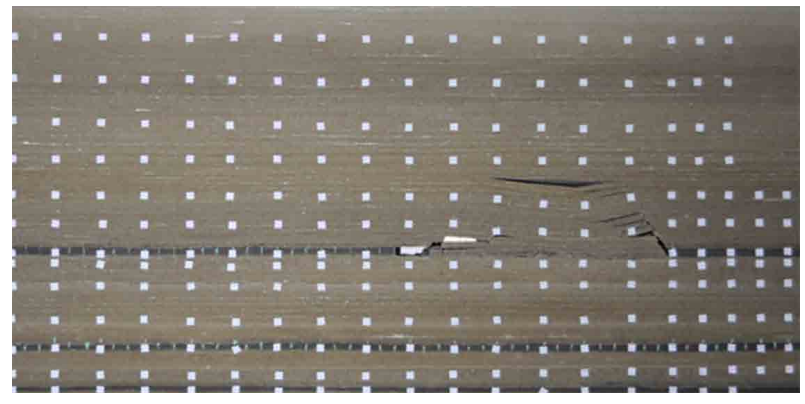

(d) Panel advance distance $100 \mathrm{~m}$

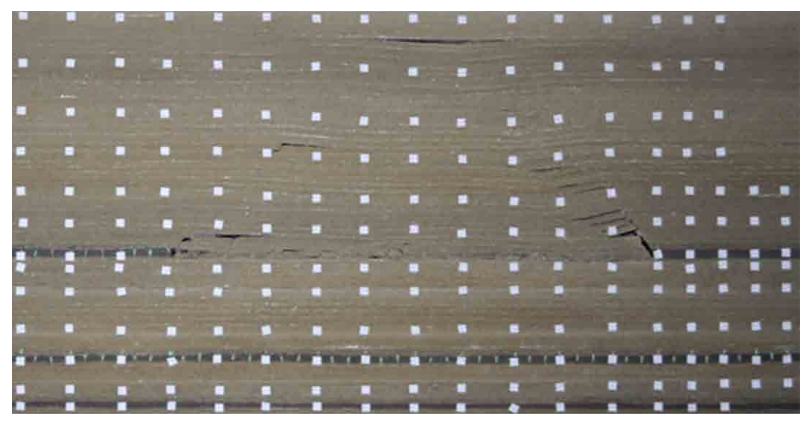

(f) Panel advance distance $150 \mathrm{~m}$

Fig. 5. Characteristics of macroscopic caving and fracture development of surrounding rock in the stope along the coal seam strike during the initial mining of the panel 66208

Fig. 6 shows the law of macroscopic caving and fracture development of surrounding rock in the stope along the coal seam strike during the repeated mining of the fully mechanized panel 66207 (Li 2017). It should be pointed out that when the panel 66208 advance distance was $180 \mathrm{~m}$, the mining of the underlying coal seam panel 66207 was carried out. It can be seen from Fig. 5 that compared with the single coal seam mining, the law of macroscopical caving and fracture development had the following new characteristics:

When the panel advance distance was less than $25 \mathrm{~m}$, there was no obvious change in rock strata between overlying and underlying coal seams. When the panel advance distance was $25 \mathrm{~m}$, the immediate roof experienced initial caving, whose height was $2.0 \mathrm{~m}$, and step distance was $25 \mathrm{~m}$. When the panel advance distance was $40 \mathrm{~m}$, the rock strata between coal seams experienced separation strata fracture. When the panel advance distance was another step distance, the basic roof strata experienced initial fracture, and the initial pressure step distance of the panel was 50 $\mathrm{m}$. At this time, the fracture zone highly developed to the coal seam floor of the panel 66208. As the panel continued to advance, the immediate roof rock mass above the coal seam caved along with mining, and the deformation and failure of surrounding rock continuously developed upward and forward, and the periodic pressure step distance was $25 \mathrm{~m}$ on average, and the pressure periodicity was obvious.

During the advancing of the panel 66207, a caving arch was formed in the overlying strata between two 


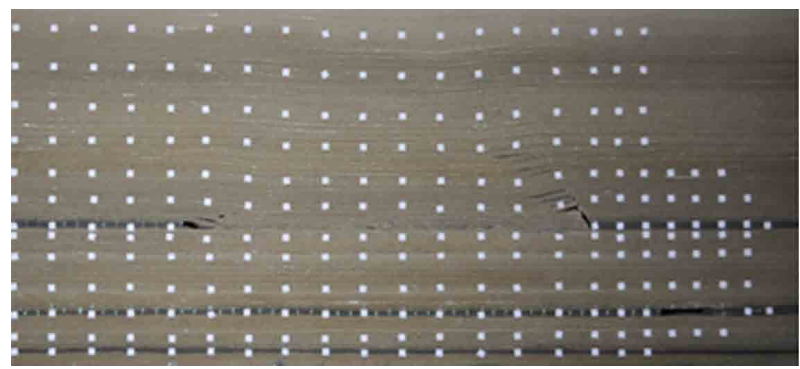

(a) Panel advance distance $25 \mathrm{~m}$

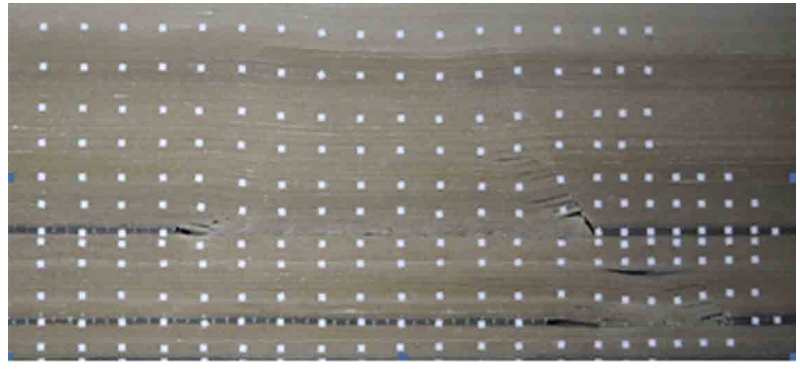

(c) Panel advance distance $75 \mathrm{~m}$



(e) Panel advance distance $125 \mathrm{~m}$

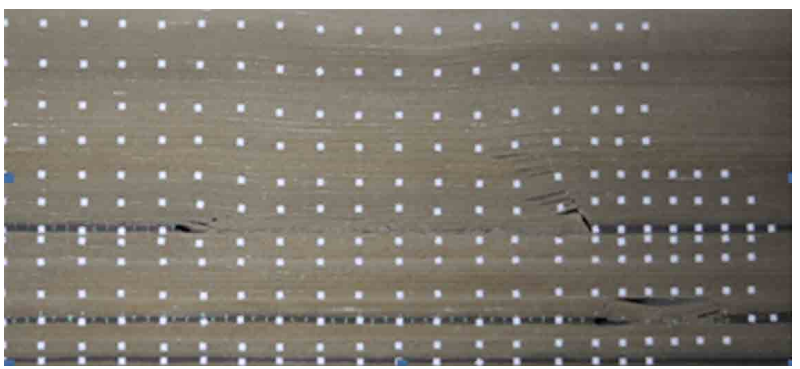

(b) Panel advance distance $50 \mathrm{~m}$



(d) Panel advance distance $100 \mathrm{~m}$

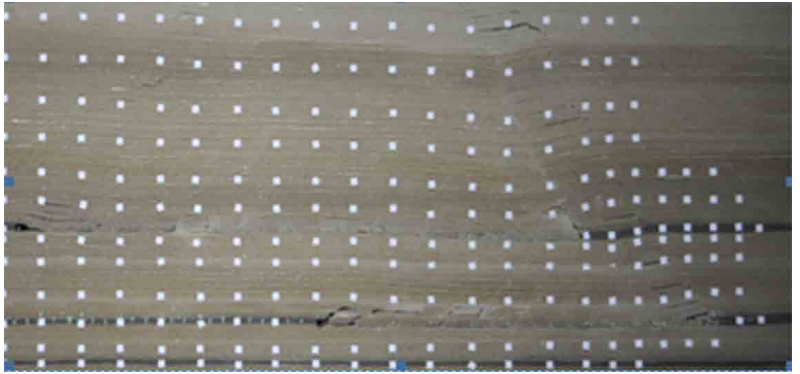

(f) Panel advance distance $150 \mathrm{~m}$

Fig. 6. Characteristics of macroscopic caving and fracture development of surrounding rock in the stope along the coal seam strike during the repeated mining of the Panel 66207

coal seams, and its arch trace line was still composed of the boundary line of separated strata and the fracture line of rock beam. As the panel continued to advance, the strata exposed in the caving arch were gradually transferred and extended to the upper strata, until the goaf of the overlying and underlying coal seam faces was through to form a whole caving arch in the space.

Before the goaf of the panel 66207 and panel 66208 was not through, the advance of the underlying coal seam face had no effect on the development of fracture in overlying coal seam. After the goaf of the panel 66207 and panel 66208 was through, with the advance of the underlying coal seam face, the extent and scope of overlying strata fractures gradually extended.

\section{Mechanical characteristics of surrounding rock during the mining of deep coal seam group}

The distribution of vertical stress, shear stress, vertical displacement and failure zone along the dip section $10 \mathrm{~m}$ behind the coal wall after mining $120 \mathrm{~m}$ of the panel 66207 is shown in Fig. 7- Fig. 10. It can be seen that with the gradual advance of the panel, the stress field of floor strata of the stope was selective, the vertical stress was completely decompressed, the shear stress was concentrated in the boundary of the stope, and the roof above the goaf was broken under the comprehensive action of mining-induced stress, which continued to extend to the upper strata. At the same time, the surrounding rock around the stope was destroyed under the action of high supporting pressure of shell foundation, which evolved with the 


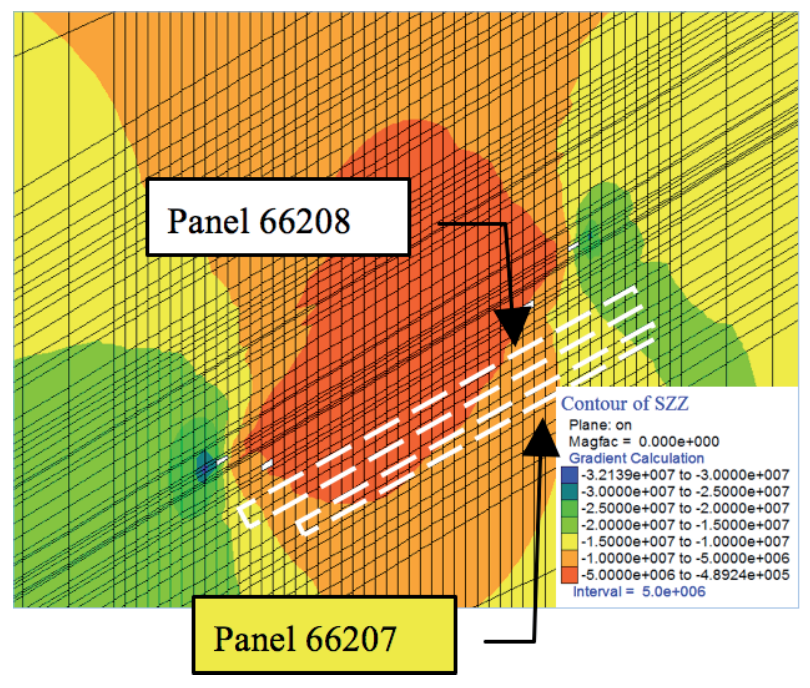

Fig. 7. Distribution of vertical stress



Fig. 8. Distribution of shear stress



Fig. 9. Distribution of vertical displacement



Fig. 10. Distribution of failure zone

advance of the panel. After the mining of the panel 66208 was completed, the stress shell composed of high stress beam was formed in the coal seam and the complete rock strata of overlying strata. The stress shell was the main bearing body of the overlying strata, and the maximum vertical displacement appeared on the roof strata of the panel. The mining of the panel 66208 broke the stress balance of original rock, causing the formation of a free space in the rock mass. The rock mass moved to the goaf, causing roof caving and floor bulging, which resulted in the rupture and heaving of underlying strata and Coal seam $\# 7$, as well as large reduction of in-situ stress. Because the overlying strata of the panel 66208 experienced stress transfer action, such as the support and compaction process of collapse and natural filling, the Coal seam \#7 experienced the process from coal seam expansion to gradual compaction with the advance of the panel 66208. If the panel 66207 was wrongly arranged in the pressure relief area of the panel 66208, the mine pressure behaviour of the panel 66207 was more relaxed than the single coal seam mining, and there was no large area pressure phenomenon.

The distribution of vertical stress, shear stress, vertical displacement and failure zone of surrounding rock in the stope of the panels 66207 and 66208 is shown in Fig. 11- Fig. 14. The calculation results showed that: the coal seam roof and floor in front of coal wall were compressed by bearing pressure; after the panel advanced, the stress was released and the floor was in the state of expansion; as the panel continued to advance, the roof strata began to cave in the goaf, and the overlying strata released the pressure; the caving gangue in the goaf compacted 


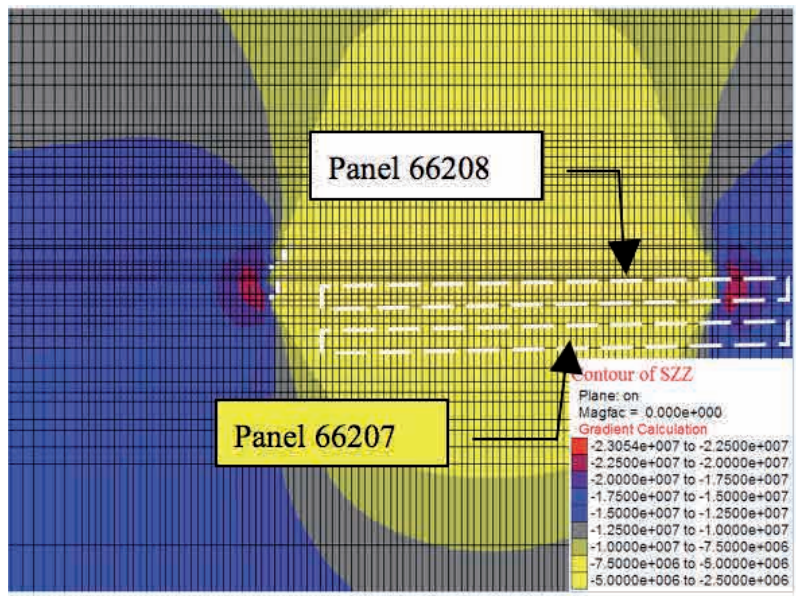

Fig. 11. Distribution of vertical stress

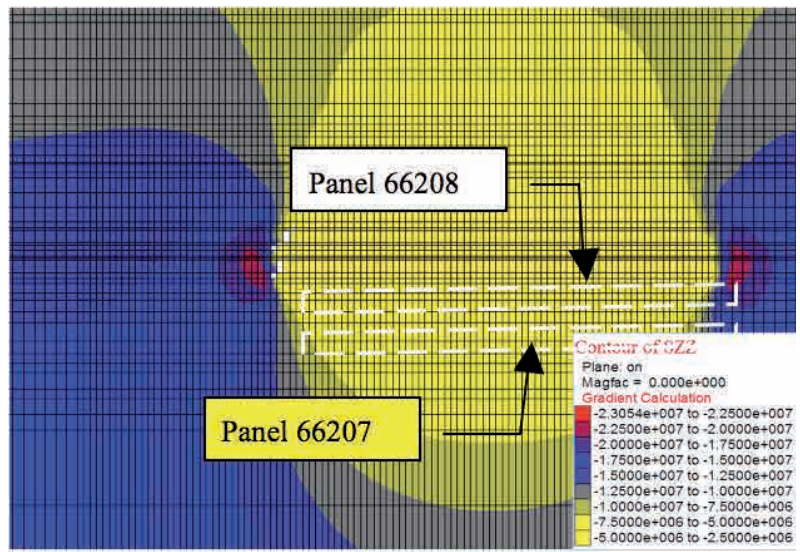

Fig. 12. Distribution of shear stress

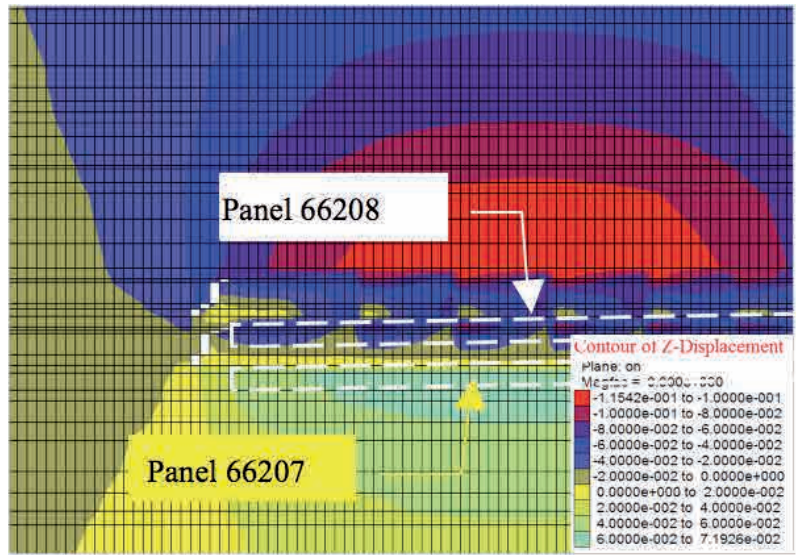

Fig. 13. Distribution of vertical displacement

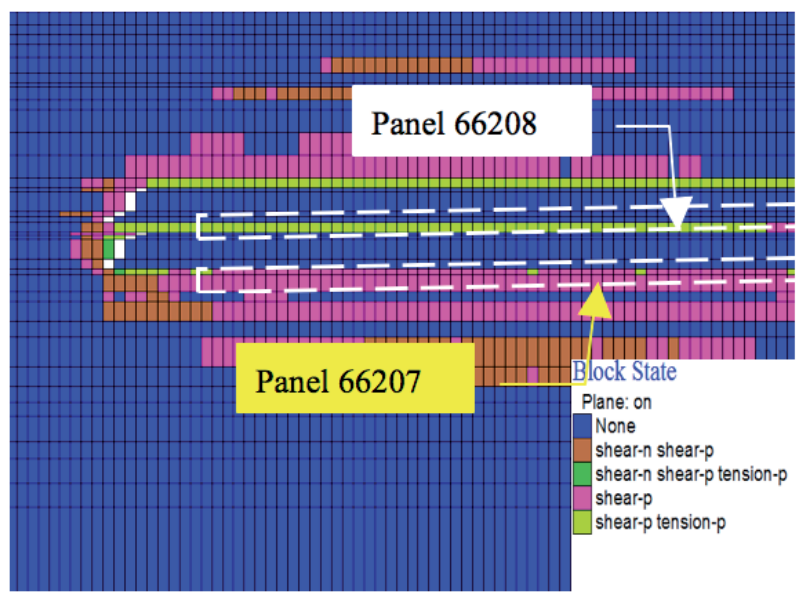

Fig. 14. Distribution of failure zone

the expanded floor; with the roof caving or the end of the roof activity, the compaction load applied to the floor became larger and larger, until the stress state of original rock was restored or nearly restored. The underlying coal seam face was always in the low stress area protected by the overlying coal seam face. There was a weak movement on the floor 10 $\mathrm{m}$ ahead of the panel 66207. If the main roof pressure was intense, it will aggravate its movement and the deformation and destruction of the coal body. During the advancing of large mining height panel, the coal body in front of the panel first experienced shear failure, and then developed into tensile failure. With the expansion of the superposition area of shear failure and tensile failure, the stability of coal wall became worse, and the probability of coal wall spalling increased.

\section{CONCLUSION}

The mining areas adopting the coal seam group mining mode in eastern China have entered deep mining. However, different from the single coal seam mining, the deep coal seam group mining faces a more complex surrounding rock force system due to the combined action of deep high stress and repeated mining. Moreover, the mine pressure behavior of panel also becomes increasingly serious. The dynamic behavior and mechanical mechanism in repeated mining of coal seam group is one of the key scientific problems for the safe mining of deep coal seam group. In this paper, the temporal and spatial evolution characteristics of 3D mining stress field and the law of strata activity in repeated 
mining of deep coal seam group were studied by using the method of similar material simulation and numerical simulation. The following conclusions were drawn.

Different from the single coal seam mining, in the deep coal seam mining, the overlying coal seam mining affected the migration law of overlying strata and destroyed the integrity of post-mining coal seam roof and floor. Moreover, a more complex stress superposition evolution was formed due to the influence of pressure relief in adjacent pre-mining coal seam and coal pillar stress concentration transfer in residual section.

The underlying coal seam face was always in the low stress area protected by the overlying coal seam face. There was a weak movement on the floor a certain distance ahead of the underlying coal seam face. If the main roof pressure was intense, it will aggravate its movement and the deformation and destruction of the coal body.

The strata experienced the support and compaction process of collapse and natural filling after the mining of the overlying coal seam, the integrity of main roof rock in the underlying coal seam was destroyed. As a result, the underlying coal seam face pressure was not obvious, and the mine pressure behavior in the stope was relaxed.

\section{ACKNOWLEDGMENTS}

This research was supported by the National Key R\&D Program of China (2017YFC0804202), the Anhui Provincial Natural Science Foundation (1808085QE177), and the National Natural Science Foundation of China (51774009).

\section{REFERENCES}

Ahamed A.J., Loganathan K., Ananthakrishnan S., Ahmed J. and Ashraf M.A. (2017). Evaluation of Graphical and Multivariate Statistical Methods for Classification and Evaluation of Groundwater in Alathur Block, Perambalur District, India. Applied Ecology and Environmental Research. 15 (3), 105-116.

Asghar Z., Ali W., Nasir A. and Arshad A. (2018). Atmospheric Monitoring for Ambient Air Quality Parameters and Source Apportionment of City Faisalabad, Pakistan. Acta Scientifica Malaysia. 2(1), 1-4.

Azizan N.H., Abidin Z.A.Z. and Phang I.C. (2017). Study of Cucumber Mosaic Virus Gene Expression in Capsicum Annuum. Science Heritage Journal. 1(2), 27-29.
Basheer A.O., Hanafiah M.M. and Abdulhasan M.J. (2017). A Study on Water Quality from Langat River, Selangor. Acta Scientifica Malaysia. 1(2), 01-04.

Bernabe Y. (1986). The effective pressure law for permeability in Chelmsford granite and barre granite. Int. J. Rock Mech. Min.Sci. and Geomech.Abstr. 23 (3), 267-275.

Danielson J.J., Poppenga S.K., Brock J.C., Evans G.A., Tyler D.J., Gesch D.B., Thatcher C.A. and Barras J.A. (2016). Topobathymetric Elevation Model Development using a New Methodology: Coastal National Elevation Database. Journal of Coastal Research. (76), 75-89.

Daya B. and Pant K. (2017). Biomonitoring of Wetland Using Macrophytes and Macroinvertebrates. Malaysian Journal of Sustainable Agriculture. 1(1), 11-14.

Enever J.R.E. and Henning A. (1997). The relationship between permeability and effective stress for Australian coal and its implications with respect to coalbed methane exploration and reservoir model Proceedings of the 1997 International Coalbed Methane Symposium. Tusealoosa, AL.USA: University of Alabama, 13-22.

Fan S., Ma Y. and Qin N. (2017). Basic characteristics and starting mode of debris flow in Tieshanzhang Mining Area under typhoon. Geology, Ecology, and Landscape. 1(4), 241-248.

Fu H. and Liu X. (2017). Research on the Phenomenon of Chinese Residents' Spiritual Contagion for the Reuse of Recycled Water Based on SC-IAT. Water, 9 (84611). DOI: 10.3390/w9110846.

Gao K., Liu Z.G. and Liu J. (2015). Design of outburst experiment device based on similar simulation and geomechanical model test and its application. Rock and soil mechanics, 36 (3), 711-718.

Grzeczka G. and Szymak P. (2016). The Hardware Implementation of Demonstrator Air Independent Electric Supply System Based on Pem Fuel Cell. Polish Maritime Research, 23 (4), 84-92.

Harpalani S. and Mopherson M.J. (1984). The effect of gas evacuation on coal permeability test specimens. International journal of rock mechanics and mining sciences and geomechanics abstracts, 21 (3), 161-164.

Kim N.Y., Jeon E.J., Jung S.H., Ahn S.J., Park M.A. and Seo J.S. (2018). Gene expression profiling and expression analysis of freshwater shrimp (Neocaridina denticulata denticulata) using expressed sequence tags and short-term exposure to copper. Journal of Environmental Biology. 39 (1), 51-57. DOI: $10.22438 /$ jeb/39/1/PRN-108.

Li J.Z., Yuan A.Y. and Zhu, C.Q. (2017). Study on control mechanism of loose coal working face surrounding rock and application under high gas coal seams. Fresenius environmental bulletin, 26 (12A), 485-493. 
Li S.G., Yang D., An Z.F., Li H.T. and Wei X.W. (2016). Experimental research on the shape and dynamic evolution of repeated mining-induced fractures in shortdistance coal seams. Journal of Mining and Safety Engineering, 5, 904-910.

Li Y. (2017). The Study on Temporal and Spatial Evolution Characteristics of Surrounding Rock Stress Shell for Coal Seam Group Mining. Beijing: China university of mining \& technology(Beijing).

Mohammed G.A.E.T. (2018). Productivity of Pure Stands and Intercropped Forage Sorghum and Hyacinth Bean. Malaysian Journal of Sustainable Agriculture. 2(1), 5-6.

Nawaz A., Arshad F. and Khurshid F. (2018). Evaluation of Low Cost Environment Friendly Natural Extracts for The Purification of Drinking Water. Acta Scientifica Malaysia. 2(1), 23-25.

Ong S.Q., Lee B.B., Tan G.P. and Maniam S. (2017). Capacity of black soldier fly and house fly larvae in treating the wasted rice in Malaysia. Malaysian Journal of Sustainable Agriculture. 1(1), 08-10.

Qian M.G., Xu J.L. and Wang J.C. (2018). Further on the sustainable mining of coal. Journal of china coal society, 43 (1), 1-13.

Razali M.A.A. and Said F.M. (2017). Red pigment production by monascus purpureus in stirred-drum bioreactor. Science Heritage Journal. 1(1), 13-15.

Steve Z.D.H., Chu X.Y. and Xue F.X. (1999). Dynamic nature of coal permeability ahead of a longwall face. International journal of rock mechanics and mining sciences. 36 (5), 693-699.

Sun, X., Dong, W., Shibo, Y. U., Cong, W., Zheng, Y. and Ren, X. (2014). Research on the evolutional course of surrounding rock structure along gob side with excavation of multiple working faces in close distance seam. Journal of Mining and safety engineering, 31 (4), 607-611.

Tu, S.H., Dou, F.J., Mo, Z.J., Wang, F.T. and Yuan, Y. (2011). Strata control technology of the fully mechanized face in shallow coal seam close to the above room and pillar gob. Journal of china coal society. 36 (3), 366-370.

Xie G.X., Li J.Z., Wang L. and Tang Y.Z. (2018). Mechanical characteristics and time and space evolvement of stress shell in stope floor stratum. Journal of china coal society. 43 (1), 52-61.

Xie H.P. (2017). Research framework and anticipated results of deep rock mechanics and mining theory. Advanced engineering sciences, 49 (2), 1-16.

Yang A., Han Y., Pan Y., Xing H. and Li J. (2017). Optimum surface roughness prediction for titanium alloy by adopting response surface methodology. Results in Physics. 7, 1046-1050.

DOI: 10.1016/j.rinp.2017.02.027.

Yang Z., Tong B., Huang C.C. and Wang G. (2012). Study of caving and fracturing over a longwall panel beneath a goaf mined by room and pillar. Journal of mining and safety engineering, 29 (2), 157-161.

Zahan T., Hashem A., Rahman M.M., Bell R.W. and Begum M. (2018). Efficacy of Herbicides in Non-Puddled Transplanted Rice Under Conservation Agriculture Systems and Their Effect on Establishment of The Succeeding Crops. Acta Scientifica Malaysia. 2(1), 17-25.

Zhang D.Y., Tang C.A., Liang Z.Z. and Ma K. (2017). Reinforcement effect of anti-shear tunnels of Dagangshan right bank slope based on microseismic energy evolution. Chinese journal of geotechnical engineering, 39 (5), 868-878. 